\title{
Uropatagium venation pattern in bats as diagnostic character (by the example of genus Myotis)
}

\author{
Nikolai E. Dokuchaev
}

\begin{abstract}
By the example of genus Myotis it was shown that venation pattern on uropatagium of bats in some cases can be used as diagnostic character. Venation features on uropatagium allow easy to separate Daubenton's bat, eastern water bat, big-footed bat, and pond bat from Brandt's bat, Siberian bat, whiskered bat, and Ikonnikov's bat.
\end{abstract}

KEY WORDS: bats, Chiroptera, Myotis, uropatagium, uropatagium venation.

Nikolai E. Dokuchaev [dokuchaev@ibpn.ru], Institute of Biological Problems of the North, Far Eastern Branch of the Russian Academy of Sciences, Portovaya str. 18, Magadan 685000, Russia.

\section{Рисунок жилкования межбедренной перепонки летучих мышей как диагностический признак (на примере рода Myotis)}

\section{Н.Е. Докучаев}

\begin{abstract}
РЕЗЮМЕ. На примере рода Myotis показано, что рисунок жилкования на межбедренной перепонке летучих мышей в ряде случаев может быть использован как диагностический признак. Особенности жилкования на уропатагиуме позволяют легко разделять такие виды как водяная, восточная, длиннопалая и прудовая ночницы с одной стороны и ночницы Брандта, сибирская, усатая, Иконникова с другой.
\end{abstract}

КЛЮЧЕВЫЕ СЛОВА: летучие мыши, ночницы, Myotis, жилкование межбедренной перепонки.

\section{Introduction}

When it comes to diagnostics of bats, morphological peculiarities of tail membrane (uropatagium) are used in very limited cases. Additional skin structures (e.g. postcalcareal lobe near spur) in most species of northern Myotis are undeveloped, except Myotis frater G. Allen, 1923 and M. ikonnikovi Ognev, 1912 (Strelkov, 1963). Free edge of uropatagium between the end of a spur and tail in Myotis is thin, smooth, and devoid of any morphological structures. Only a few species including M. nattereri (Kühl, 1817) and M. bombinus Thomas, 1906, where "uropatagium's free edge between the ends of spurs and tail thickened, serrated, and densely covered with stiff bristles located on the edge in two parallel rows" are exception here (Bobrinskiy et al., 1965: 91). This character is extremely stable and allows to distinguish accurately these bats from the other Palearctic Myotis (Kuzyakin, 1950). A good diagnostic character for separation of $M$. gracilis Ognev, 1927 (=M. sibirica Kaschenko, 1905, see Kruskop (2012)) and M. ikonnikovi proved to be the shape of the veins in the uropatagium (Kondo \& Sasaki, 2005; Kawai et al., 2006; Kawai, 2009). Myotis gracilis has a "straight type" venous vessel, whereas M. ikonnikovi has a "dogleg type" one. These examples actually confine the usage of these morphological structures in the uropatagium as diagnostic characters. In species essays, how- ever, features of hirsuties on uropatagium in different species are described (Kuzyakin, 1950: 233), but the feature of the venation is not mentioned even there. In beautifully illustrated book on bats of Europe (Dietz \& von Helversen, 2004) the authors also did not pay attention on the differences in venation in uropatagium.

The venation pattern on a bat's membrane is formed by muscles (or separate muscle fibers), nerves, blood vessels, and the system of the connective tissue fibers (Kowtun, 1979). The latter (collagen and elastic fibers) are the most abundant components of venation in plagiopatagium and present in all of its parts. This venation component in the representatives of different genera and species of bats is the most variable of all the above described. This refers to the number of connective tissue fibers in different parts of the bat's membrane, their direction and thickness (Kowtun, 1979). An example of three species of European pipistrelles separation on the features in plagiopatagium venation is shown by Dietz and von Helversen (2004).

Among the bats from Russian Far East there is often a difficulty in $M$. petax and $M$. sibirica identification. This happens due to their similar sizes and instability of certain diagnostic features used as identification keys. For example, on the dry skin, it may be impossible to determine the exact point of the wing membrane attachment to the hind foot. These species do not differ also in some dental characters (presence of protocones on the 


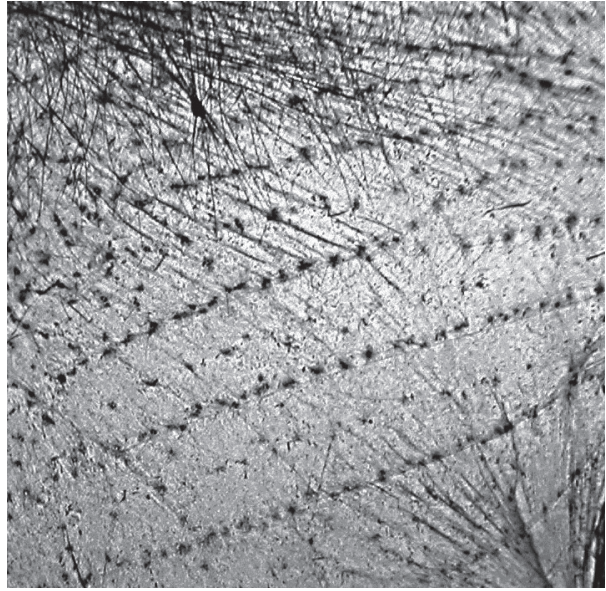

Fig. 1. Fragment of Myotis sibirica uropatagium (enlarged).

molars) (Tiunov, 1984, 1997). Meanwhile, by studying the collection of Myotis from Russian Far East, I discovered that the venation pattern on uropatagium makes it easy to distinguish these species. In this paper, types of the uropatagium venation are considered that allow to easy separation of some pairs of the Myotis species.

\section{Material and methods}

Dry Myotis skins have been investigated in Zoological Institute of the Russian Academy of Sciences (RAS) (Saint Petersburg), Institute of Animals Systematics and Ecology of the Siberian Branch of RAS (Novosibirsk), and the Institute of Biological Problems of the North of the Far Eastern Branch of RAS (Magadan), and for some species, pictures of uropatagium have been made. The following species had been studied: $M$. brandtii (Eversmann, 1845) — 50 specimens, M. dasy- cneme (Boie, 1825) — 78, M. daubentonii (Kühl, 1817) - 48, M. ikonnikovi - 5, M. mystacinus (Kühl, 1817) - 134, M. nattereri - 25, M. petax Hollister, 1912 - 53, M. sibirica - 57, M. macrodactylus (Temminck, 1840) - 8 specimens.

\section{Results and discussion}

Venation pattern of the wing membrane within Chiroptera is very variable, both qualitatively and quantitatively. Quantitative differences can be well expressed even in closely related species (Yablokov et al., 1974; Kowtun, 1979). Without going into fine structure, we focus only on the external morphology of the venation. Throughout their length, more or less evenly spaced spots are clearly visible on the lumen (Fig. 1). In each of them there is one hair, or a group of hairs. Since hair follicles combined with sebaceous and sweat glands, these structures form a spot in the complex. Actually, these spots with their internal structures (muscle and collagen fibers) create the pattern of the membrane venation.

Venation number on uropatagium varies considerably in different bats species. E.g., on uropatagium of M. nattereri we can count 6 venation rows (Fig. 2A). Only venations running parallel to the outer edge of uropatagium are numbered in this figure, although we can also see other venations oriented differently. In $M$. petax (Fig. 2B) and M. daubentonii, on the contrary, venation is frequent, and rows number is even difficult to calculate. In any case, their number is no less than 20 . The same venation pattern was observed in $M$. dasycneme and $M$. macrodactylus. In $M$. sibirica and $M$. brandtii venations arranged more sparsely. It looks like they have densely populated venation spots alternated with those where spots are located very rarely, although their general direction is visible (Figs 1 and 2D). Also

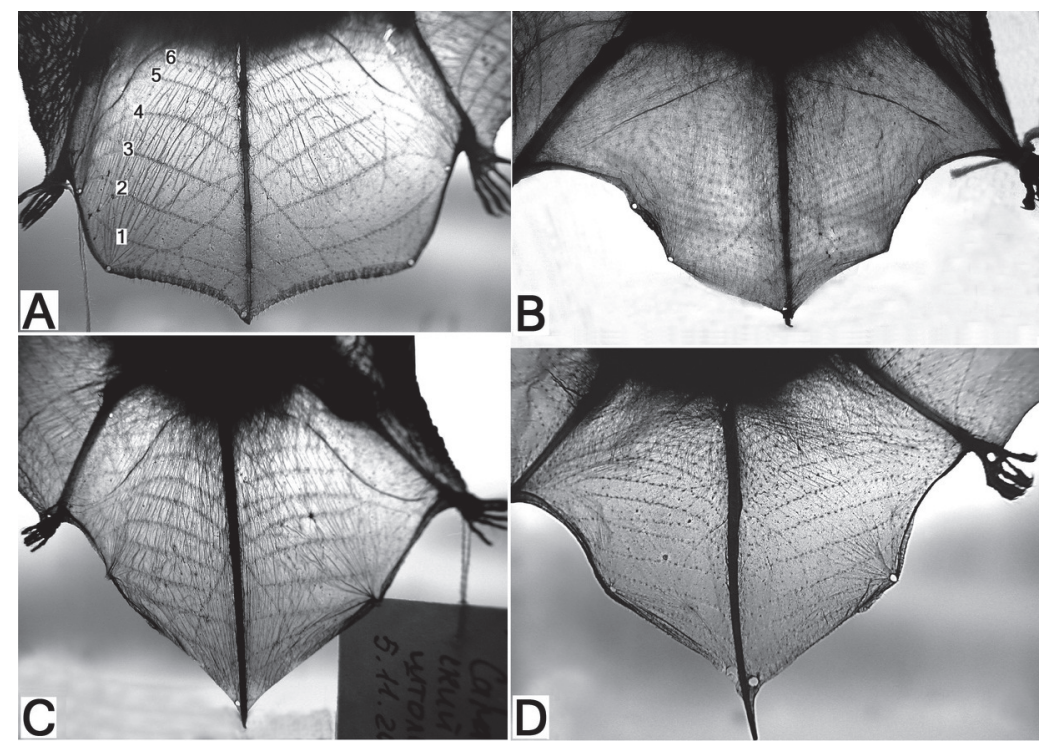

Fig. 2. Venation patterns of uropatagium in Myotis: A - M. nattereri, B - M. petax, C - M. brandtii, D - M. sibirica. 

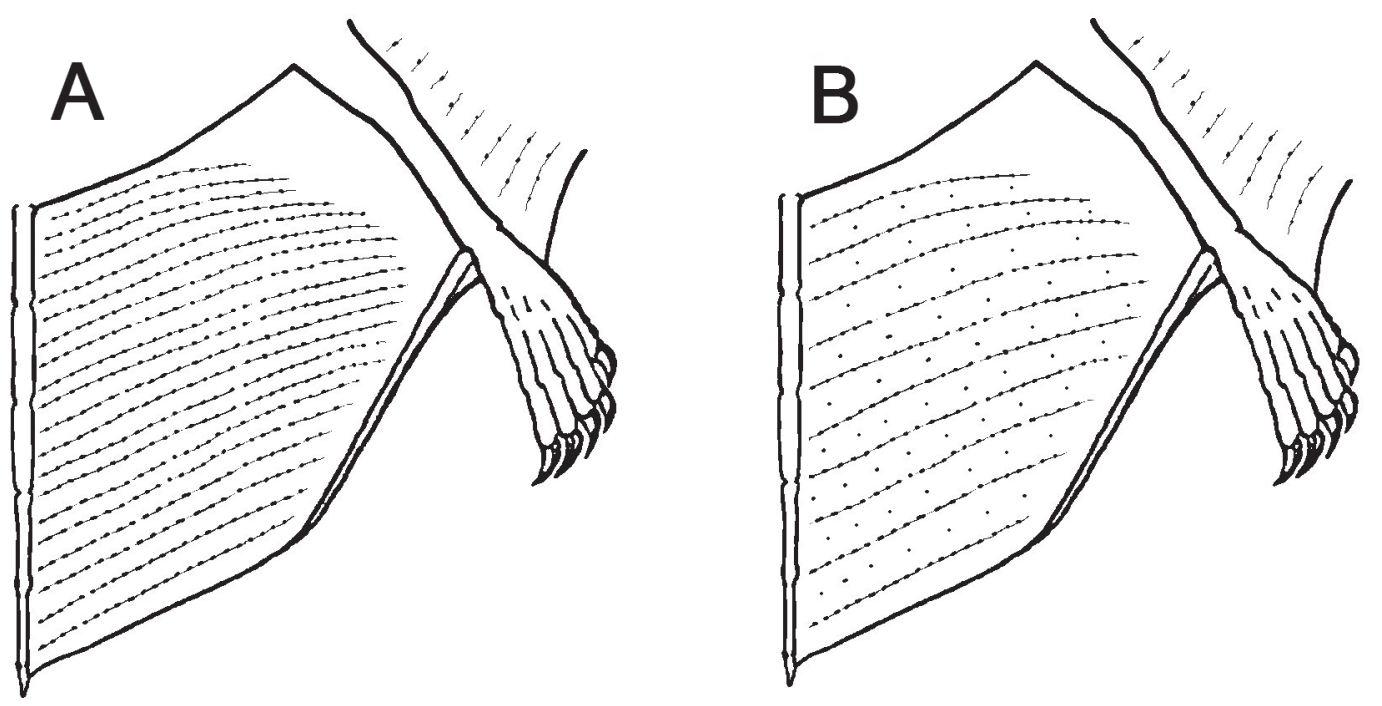

Fig. 3. Two types of uropatagium venations patterns in Myotis: A - M. dasycneme, M. daubentonii, M. macrodactylus, and M. petax; B - M. brandtii, M. frater, M. ikonnikovi, M. mystacinus, and M. sibirica.

there are differences in the nature of venation location. In some Myotis, a distance between the venations is approximately the same throughout the uropatagium (Fig. 2C), whereas in others may be observed narrowing of the space between them in the direction from the edge of the membrane to the body (Fig. 2D). Judging by the labels, such differences may occur in the same species from the one local population. However, the number of veins and their placement on the uropatagium was stable enough.

It should be noted that recently separated by the molecular genetic methods (Matveev et al., 2005; Kruskop et al., 2012), such species pairs as M. petax and $M$. daubentonii on a one hand, and M. sibirica and $M$. brandtii on the other, do not differ in the uropatagium venation.

Thus, among the studied bats' species, fewest venations on uropatagium were observed in M. nattereri. In M. dasycneme, M. daubentonii, M. macrodactylus, and M. petax, on the quantitative contrary, the number of venations is maximal and pattern is formed with uniformly distributed lines of fibers and spots on a membrane (Fig. 3A). In M. brandtii, M. frater, M. ikonnikovi, M. mystacinus, and $M$. sibirica the alternating lines are observed with frequent and rare spot locations on them and in the intermediate lines (with a rare location spots) fiber is practically not expressed (Fig. 3B).

It is noteworthy that the same pattern of venation in uropatagium was found in species that are not related but using similar hunting habitats. Thus, $M$. dasycneme, M. daubentonii, M. macrodactylus, and M. petax hunt mostly above water surface, while the other examined species forage in the different forest localities.

The proposed approach for using venation pattern on the uropatagium for the bat's diagnosis is primarily directed to separate species of similar body size and other morphological characteristics. Most certainly it requires further development and accumulation of data on the number of veins in different species. At the same time it is obviously promising, particularly for quick diagnostics by gathering biological material from living animals.

ACKNOWLEDGMENTS. I would like to thank all reviewers for their helpful comments and useful recommendations regarding early versions of the manuscript. I am grateful also to curators of mammal collections in Zoological Institute of the Russian Academy of Sciences and Institute of Animals Systematics and Ecology of the Siberian Branch, Russian Academy of Sciences for the opportunity to work there.

\section{References}

Bobrinskiy N.A., Kuznetsov B.A. \& Kuzyakin A.P. 1965. [Identification Guide to the Mammals of the USSR]. Moscow: Prosveshchenie. 384 p. [in Russian].

Dietz C. \& von Helversen O. 2004. Illustrated Identification Key to the Bats of Europe. Electronic Publication. Ver.1.0. Tuebingen \& Erlangen, Germany. Available at http:// www.uni-giessen.de/cms/fbz/fb08/Inst/tsz/st/downloads/ bats-identification-key.

Kawai K., Kondo N., Sasaki N., Fukui D., Dewa H., Sato M. \& Yamaga Y. 2006. Distinguishing between cryptic species Myotis ikonnikovi and M. brandtii gracilis in Hokkaido, Japan: evaluation of a novel diagnostic morphological feature using molecular methods // Acta Chiropterologica. Vol.8. No.1. P.95-102.

Kawai K. 2009. Myotis gracilis Ognev, 1927, Myotis ikonnikovi Ognev, 1912 // Ohdachi S.D., Ishibashi Y., Iwasa M.A. \& Saitoh T. (eds.). The Wild Mammals of Japan. Kyoto: Shoukadoh Book Sellers. P.96-100. 
Kondo N. \& Sasaki N. 2005. An external taxonomic character suitable for separating live Myotis ikonnikovi and $M$. mystacinus // Mammal Study. Vol.30. P.29-32.

Kowtun M.F. 1979. [On the nature of venation of the patagium in Chiroptera] // Zoologicheskii Zhurnal. Vol.58. No.2. P.207-217 [in Russian].

Kruskop S.V. 2012. Order Chiroptera // Pavlinov I.Ya. \& Lissovsky A.A. (eds.). The Mammals of Russia: A Taxonomic and Geographic Reference. Moscow: KMK Sci. Press. P.73-126.

Kruskop S.V., Borisenko A.V., Ivanova N.V., Lim B.K. \& Eger J.L. 2012. Genetic diversity of northeastern Palaearctic bats as revealed by DNA barcodes // Acta Chiropterologica. Vol.14. No.1. P.1-14.

Kuzyakin A.P. 1950. [Bats]. Moscow: Sovetskaya nauka. 444 p. [in Russian].

Matveev V.A., Kruskop S.V. \& Kramerov D.A. 2005. Revalidation of Myotis petax Hollister, 1912 and its new status in connection with M. daubentonii (Kuhl, 1817) (Vespertilionidae, Chiroptera) // Acta Chiropterologica. Vol.7. No.1. P.23-37.

Strelkov P.P. 1963. Order Chiroptera // Gromov I.M., Gureev A.A., Novikov G.A., Sokolov I.I., Strelkov P.P., Chapsky K.K. [Mammals of the USSR Fauna. Vol.1]. Moscow \& Leningrad: Izdatelstvo Akademii nauk SSSR. P.122-218 [in Russian].

Tiunov M.P. 1984. Order Chiroptera Blumenbach, 1779 // Krivosheev V.G. (ed.). [Terrestrial Mammals of the USSR Far East. Identification Key]. Moscow: Nauka. P.73101 [in Russian].

Tiunov M.P. 1997. [Bats of the Russian Far East]. Vladivostok: Dalnauka. 134 p. [in Russian].

Yablokov A.V., Panyutin K.K. \& Panina G.A. 1974. [Venation features of the wing membrane in some bats (Chiroptera, Mammalia)] // Vorontsov N.N. (ed.). [Theriology]. Novosibirsk: Nauka. Vol.2. P.48-56 [in Russian]. 